International Journal of Advanced Chemistry, 2(2)(2014) $185-187$
International Journal of Advanced Chemistry
Journal home page: $\begin{gathered}\text { www.sciencepubco.com/index.php/IJAC } \\ \text { doi: } 10.14419 / \text { ijac.v2i2.3549 } \\ \text { Research Paper }\end{gathered}$

\title{
Chemical composition and phytochemical properties of mango (mangifera indica.)seed kernel
}

\author{
Orijajogun O.Joyce $^{1 *}$, Batari M.Latayo ${ }^{2}$, Aguzue C. Onyinye ${ }^{1}$ \\ ${ }^{1}$ Sheda Science and Technology Complex, Km 10 from Gwagwalada, Abuja-Lokoja Express, Abuja, Nigeria \\ ${ }^{2}$ National Research Institute for Chemical Technology, PMB 1052, Basawa Zaria, Nigeria \\ *Corresponding author E-mail: joycejoseph06@yahoo.com
}

\begin{abstract}
The seed kernel of (Mangifera indica) obtained from Kwali FCT,Abuja were studied for the phytochemical,proximate analysis and mineral composition. The proximate composition reveals; moisture (5.9\%), Ash (2.43\%), crude protein (5.20\%), carbohydrate (76.14\%) and crude fibre $(0.49 \%)$.The result of the mineral composition showed potassium $(116.9 \mathrm{ppm})$, sodium $(23.1 \mathrm{ppm})$, calcium $(0.26 \mathrm{ppm})$ and magnesium $(0.56 \mathrm{ppm})$. The result of phytochemical studies of extract show the presence of alkaloids, steroids, tannins, phenol, resins, glycoside and volatile oil but saponins and phlobatannins are absent. The presence of some of these metabolites confirms the usefulness of the plant in the treatment of various diseases.
\end{abstract}

Keywords: Mangifera Indica, Phytochemical, Proximate Composition and Metabolites.

\section{Introduction}

Mangos belong to the family Mangifera. The genus plant consisting of numerous species of tropical fruiting tree in the flowering plant family Anacardiaceae. The fruit trees are commonly known as Mangos (Maginfera indica L.) is one of the most commonly known important fruits worldwide. It is widely grown and cultivated in many tropical regions. The mango is indigenous to the Indian subcontinent, Southeast Asia and Africa (Fowomola et al. 2010).

Mango trees (Mangifera indica L.) grow up to 35-40 m (115-130 $\mathrm{ft}$.) tall, with a crown radius of $10 \mathrm{~m}(33 \mathrm{ft}$.). The trees are longlived, as some specimens still fruit after 300 years. In deep soil, the taproot descends to a depth of $6 \mathrm{~m}$ (20 ft.), with profuse, widespreading feeder roots; the tree also sends down many anchor roots, which penetrate several feet of soil. The leaves are evergreen alternate, simple, $15-35 \mathrm{~cm}(5.9-14$ in) long and $6-16 \mathrm{~cm}$ (2.4-6.3 in) broad; when the leaves are young they are orangepink, rapidly changing to a dark, glossy red, then dark green as they mature. It is one of the most recommended fruits which have medicinal importance to fight beriberi, heal bronchial diseases and cure brain fatigue, mental depression, wrestle heart burn and insomnia (Medina ET al.2002).

It's the most widely exploited fruits for food, juice, flavor and fragrance a common ingredient in new functional foods often called super fruits(Kittiphoom et al. 2012).Antioxidants and enzymes present in the mango fruits are believed to play an important role in the prevention and in the protection of cancer (colon, breast, leukemia and prostate) and heart disease. Presence of fibre and enzymes makes mangoes favorite for healthy digestion. Some of the flavonoids present in the fruit are believed to strengthen the immune system of human body. The purpose of this work is to determine the proximate, phytochemical properties and mineral content of Mango kernel (Maginfera indica L.).

\section{Materials and methods}

\subsection{Plant materials}

The mango fruits (Mangifera indica) were collected from Kwali market, in Kwali Area Council, FCT Abuja, Nigeria.

\subsection{Chemicals and reagents}

All the chemical and reagents used in this study were of analytical grade and were products of British Drug House Laboratory, England.

\subsection{Processing of plant samples}

The mango seeds were dehulled, the kernels were removed from the seed coat, then rinsed in sterile distilled water and were sun dried.

\subsection{Extraction of plant samples}

Oil Extraction: The kernels were pulverized using an electric blended. The pulverized sample $80 \mathrm{~g}$ was inserted into the soxhlet extractor and hexane was used as the extraction solvent for a period of eight hours was extracted using hexane by adopting the method described by Association of Official Analytical Chemist (AOAC, 1998).At the end of the extraction period, the solvent was recovered by rotary evaporator and residual oil was collected and stored in a pre-weighed container for the phytochemical screening.

\subsection{Phytochemical screening}

The extract of Mangifera indica seed was screened for the presence of phytochemical constituents such alkaloids, tannins, 
terpenoids, flavonoids, balsams, saponins, sterols, cardiac glycosides and volatile oil using standard method as described by (Trease 2002 and Sofowora 2008)

\subsection{Proximate analysis}

Proximate analysis of Mangifera indica seed Moisture, crude protein (micro-Kjeldahl), crude fiber and oil (Soxhlet) contents were determined using the methods described by (Pearson 1976) whereas the ash content was determined using the method of (Pomeranz 1994) and total carbohydrate was determined by difference.

\subsection{Ash content determination}

A porcelain crucible was washed and dried in a hot air oven for 30 minutes at a Temperature of $105^{\circ} \mathrm{C}$. After heating, it was then cooled in a desiccator for 30 minutes. The crucible was weighed using analytical balance. $2 \mathrm{~g}$ of sample was weighed into the porcelain crucible and its weight was recorded. It was then charred using a Bunsen flame to de-carbonize it after which it was transferred to a muffle furnace maintaining a temperature of $500^{\circ} \mathrm{C}$ for one hour, for complete de-carbonization to obtain white ash. The crucible and ash were cooled and the weight was recorded. The result was expressed as percentage of the weight of ash over the original weight of sample.

\subsection{Moisture content determination}

This is a measure of the percentage moisture lost due to drying at a temperature of $105^{\circ} \mathrm{C}$. According to (Udo et al 1986) method, $2 \mathrm{~g}$ of the powdered leaves was weighed $\left(\mathrm{W}_{1}\right)$ into reweighed crucible $\left(\mathrm{W}_{\mathrm{o}}\right)$ and placed into a hot drying oven at $105^{\circ} \mathrm{C}$ for $3 \mathrm{~h}$. The crucible were removed, cooled in desiccators and weighed. The process of drying, cooling and weighing were repeated until a constan weight $\left(\mathrm{W}_{2}\right)$ was obtained. The weight loss due to moisture was obtained by the equation:

Moisture $(\%)=\frac{\mathrm{W} 1-\mathrm{W} 2}{\mathrm{~W} 1-\mathrm{Wo}} \times 100$

Where:

$\mathrm{W}_{\mathrm{o}}=$ Weight of the empty crucible $(\mathrm{g}) \mathrm{W}_{1}=$ weight of the powder sample + empty crucible $(\mathrm{g}) \mathrm{W}_{2}=$ weight of dried sample + empty crucible $(\mathrm{g})$

\subsection{Crude fibre determination}

$3 \mathrm{~g}$ of the defatted sample was placed in the round bottom flask containing $200 \mathrm{ml}$ of $0.13 \mathrm{M} \mathrm{H}_{2} \mathrm{SO}_{4}$ and was refluxed for 30 minutes. The solution was filtered through a lien cloth on a funnel and washed with boiling water. The residue was transferred to a beaker and boiled for 30 minutes with $200 \mathrm{ml} 0.313 \mathrm{M} \mathrm{NaOH}$. The residue with $50 \mathrm{ml}$ of acetone to remove any further trace of oil, and placed in a crucible this was then dried in the oven at $105^{\circ} \mathrm{C}$ for one hour and then incinerated in the Muffle Furnace.

The result is expressed as:

Crude fibre $(\%)=\frac{\text { weight of crude fibre }}{\text { Weight of sample }} \quad \frac{100}{1}$

\subsection{Protein determination}

$2 \mathrm{~g}$ of sample and $8 \mathrm{~g}$ of catalyst mixture were weighed in a filter paper and placed in a digestion flask. $20 \mathrm{ml}$ of conc. $\mathrm{H}_{2} \mathrm{SO}_{4}$ solution was poured into the flask and the flask was heated in an inclined position. Heating continued with occasional swirling until solution turned colorless, the resulting solution was then diluted to $100 \mathrm{ml}$ in a volumetric flask with distilled water. The digested sample was distilled, using $10 \mathrm{ml}$ solution of $50 \% \mathrm{NaOH}$ and the distillate in the beaker containing $10 \mathrm{ml}$ of $1 \%$ boric acid with screened methyl red as indicator. This was titrated with $0.05 \mathrm{M}$ $\mathrm{H}_{2} \mathrm{SO}_{4}$ solution. The result was expressed as:
$\%$ Nitrogen $=\underline{\text { sample titre- Blank titre }} \underline{0.0014100}$

Sample weight $\frac{0}{1}$

Where 0.0014 is the $\mathrm{g}$ of nitrogen in $0.05 \mathrm{M} \mathrm{H}_{2} \mathrm{SO}_{4}$ and $10 \mathrm{ml}$ is the dilution factor.

Crude protien $(\%)=\%$ Nitogen $\times 5.83$

\subsection{Fat content determination}

A $250 \mathrm{ml}$ round bottom flask was washed and dried in oven for one hour at $105^{\circ} \mathrm{C}$. It was then cooled in the desiccator and weighed. The thimbles were washed with the solvent used for extraction, dried in the oven and cooled in the desiccator. $2 \mathrm{~g}$ of moisture free samples was weighed, wrapped, with filter paper and placed in the thimble which was then plugged with defatted (soaked in ether) cotton wool with $200 \mathrm{ml}$ of petroleum spirit in a round bottom flask and the extraction was carried out for six hours. After extraction, the solvent was distilled off and the weight of residual fat was noted and this was calculated as a percentage of the sample used.

\subsection{Carbohydrate content determination}

In food decomposition table, the carbohydrate content is usually given as total

Carbohydrate by difference. That is the percentage of water, protein, crude fibre, fat and ash subtracted from $100 \%$

Carbohydrate content $=100 \%-(\%$ moisture $+\%$ protein $+\%$ ash + $\%$ fat $+\%$ fibre)

\subsection{Preparation of samples for mineral determination}

Two grams (2g) of each of the dried powered samples were weighed into separate beakers using micro weighing balance and then treated with $20 \mathrm{ml}$ of concentrated $\mathrm{HNO}_{3}$, heated to reflux on an electric hot plate at $80-100{ }^{\circ} \mathrm{C}$ until digestion is complete. Side by side $20 \mathrm{ml}$ of conc. $\mathrm{HNO}_{3}$ was also added to empty beaker which served as blank. The content of the beaker is allowed to cool,filtered through Whatman No 42 filter paper into volumetric flasks and made up to volume of $100 \mathrm{ml}$ with deionised water, stored in clean polyethylene bottles and mineral contents determined using(Thermo scientific I c e 3000 series) atomic absorption spectrophotometer. These bottles and flasks were rinsed in dilute hydrochloric acid $(0.10 \mathrm{M} \mathrm{HCl})$ to arrest microbial action which may affect the concentrations of the anions and cations in the samples. The instrument was calibrated with standard solutions. The flasks were then covered.

\subsection{Determination of minerals}

The mineral content of samples were analyzed by (AOAC,1998) using the Atomic Absorption spectrophotometer (Thermo Scientific I C E 3000 series) but $\mathrm{Na}$ and $\mathrm{K}$ were determined by flame photometer (Seta flash series 7). All the reagents and chemicals used were of analytical grade and obtained from BDH. Acid washed glassware and de-ionized water was used throughout the analysis. The digested samples in conc. HNO3 were made up to $100 \mathrm{ml}$ and stored in polypropylene container. Four working standards $(1000 \mathrm{ppm})$ and a blank were prepared for each of the mineral elements i.e. $\mathrm{Ca}, \mathrm{Fe}, \mathrm{Mn}, \mathrm{Mg}, \mathrm{K}, \mathrm{Na}$, and $\mathrm{Pb}$ in conc. HNO3.Absorbance was noted for standard solution of each element in the samples using Atomic Absorption Spectrophotometer (AAS). The blank readings were also taken and the concentrations of various elements were computed in $\mathrm{mg} / \mathrm{l}$. The mineral contents determined were computed and recorded.

\section{Results and discussion}

\subsection{Phytochemical screening}


The results of phytochemical screening from Table 1 below, showed the presence of some secondary metabolites which are alkaloids, flavanoid, tannins, glycosides, resins,phenol and steroids. Tannins and glycosides have been reported to have antibacterial potentials (Dangoggo et al.2001). It should be noted that steroidal compounds are of importance and interest in pharmacy due to sex hormones (Okuwa et al.2001). The presence of alkaloids and terpenoids in the seed of Mangifera indica indicated it as a natural agent for antibacterial and antifungal botanicals.

Table 1: Phytochemical Screening of the Sample (Mangifera Indica L.)

\begin{tabular}{ll}
\hline Test & HEX \\
\hline Steroids & + \\
Tannins & + \\
Alkaloids & + \\
Flavonoids & + \\
Cardiac glycoside & - \\
Phlobatannins & + \\
Terpenoids & + \\
Volatile oil & + \\
Phenol & + \\
Resins & + \\
Glycosides & - \\
Saponins & \\
\hline
\end{tabular}

(+) Present; (-) absent. (HEX): Hexane Extract

Table 2: The Result of the Proximate Composition Is of the Sample (Mangifera Indica L.).

\begin{tabular}{ll}
\hline Test & Composition \\
\hline Proximate & \\
Carbohydrate $(\%)$ & 76.14 \\
Crude fibre (\%) & 0.49 \\
Ash (\%) & 2.43 \\
Fat (\%) & 9.84 \\
Moisture Content $(\%)$ & 5.90 \\
Crude protein (\%) & 5.20 \\
& \\
Minerals & \\
$\mathrm{K}(\mathrm{ppm})$ & 116.9 \\
$\mathrm{Mg}(\mathrm{ppm})$ & 0.56 \\
$\mathrm{Ca}(\mathrm{ppm})$ & 0.26 \\
$\mathrm{~Pb}(\mathrm{ppm})$ & $\mathrm{NA}$ \\
$\mathrm{Fe}(\mathrm{ppm})$ & 0.01 \\
$\mathrm{Mn}(\mathrm{ppm})$ & 0.01 \\
$\mathrm{Na}(\mathrm{ppm})$ & 23.1 \\
\hline
\end{tabular}

NA $=$ Not Applicable

The summary of the proximate composition of Mangifera indica L seed is shown in Table 2 above.

The proximate composition of Mangifera indica L seed had moisture content,crude protein,carbohydrate,fat,crude fibre and ash as $5.90 \%, 5.20 \%, 76.14 \%, 9.84 \%, 0.49 \%$ and $2.43 \%$ respectively. The moisture content is comparable to moisture content of the kernel of Irvingia gabonensis (Ogunsina et al.2012).The long shelf life could be attributed to the low moisture content as high moisture content can hasten food spoilage and also enhances microbial growth (Gunawan 2013). The ash and protein contents of this seed indicates that it could be a good source of feed for livestock and enhance palatability (Hounsome et al.2008).

\subsection{Mineral composition}

The trend of the abundance of the mineral content in the seed of Manginfera indica in (Table 2) followed $\mathrm{K}>\mathrm{Na}>\mathrm{Mg}>\mathrm{Ca}>\mathrm{Fe}$ $>\mathrm{Mn}>\mathrm{Pb}$. These macro elements play a vital role in our bodies metabolism,potassium and sodium regulates the acid base balance of the body fluids and also form major cations of intracellular fluid. These metals are necessary for normal physiological functions.

\section{Conclusion}

The result of the phytochemical analysis shows the presence of some metabolites which confirms the usefulness of the plant in the treatment of various diseases. The high carbohydrate content of
Manginfera indica makes it a promising raw material in the starch and allied industry and also a good source of protein in livestock feed.

\section{References}

[1] Fowomola,M.A.(2010),Some nutrients and antinutrients content of mango(Mangifera indica) seed.African Journal of food science.4(8):472-476.

[2] Medina J, De La Cruz,Garcia H S.(2002),Mango post-harvest operations organization:Instituto Technologico de Veracruz.

[3] Kittiphoom,S.(2012),Utilization of mango seed.International food Research Journal.19(4):1325-1335.

[4] Pearson, D. (1976), the Chemical Analysis of Foods. 7th Edn. R.K. ChurchillLivingstone, Edinburgh, U.K.pp:488-496.

[5] Pomeranz, Y. and C. Meloan.(1994), Food analysis:Theory and practice, 3rd Edn., New York: Chapman and Hall, pp: 778

[6] AOAC: Official Methods of analysis of the Association of Official Analytical Chemists, 16th Edition. (1998), Gaithersburg, USA.

[7] Dangoggo, S.M.,U.Z. Faruq and S.B.Manga (2001),Preliminary Phytochemical and Antibacterial Analysis of Mangifera indica.Nigeria Journal of Physical and Mathematical Sciences, 1(1),28-33.

[8] Okuwa D.E.(2001).Evaluation of the chemical Composition of spices and flavoring Agent.Global Journal of pure and Applied science, 7(3):455-459.

[9] Ogunsina,B.S,Bhatnagar, A.S,Indira T.N, and Radha,C.(2012), The proximate composition of African Bush mango kernels(Irvingia gabonensis) and characteristics of its oil.Ife Journal of science Vol.14 No.1.

[10]Gunawan, S,Darmwan,R.,Nanda M.,Setiawan A.M.,Fansuri H.(2013),Proximate composition of Xylocarpus moluccensis seeds and their oils.Industrials crops and products.41,107-112.

[11]Hounsome N.Hounsome B.,Tomos D.and Edwards Jones G.(2008),Plant metabolites and Nutritional quality of vegetables.Journal of food science.73,NR 4,R48-R65 http://dx.doi.org/10.1111/j.1750-3841.2008.00716.x. 